\title{
MAGNETIC CIRCULAR DICHROISM OF OPAL CRYSTALS INFILTRATED WITH IRON PORPHYRIN*
}

\author{
A. Rėza ${ }^{\text {a,b }}$, I. Šimkiené ${ }^{\text {a }}$, G.J. Babonas ${ }^{\text {a }}$, R. Vaišnoras ${ }^{\text {b }}$, D. Kurdyukov ${ }^{\text {c }}$, and \\ V. Golubev ${ }^{\mathrm{c}}$ \\ ${ }^{a}$ Semiconductor Physics Institute, A. Goštauto 11, LT-01108 Vilnius, Lithuania \\ E-mail: jgb@pfi.lt \\ ${ }^{\mathrm{b}}$ Vilnius Pedagogical University, Studentu 39, LT-08106 Vilnius, Lithuania \\ ${ }^{\mathrm{c}}$ Ioffe Physico-Technical Institute RAS, 194021 St. Petersburg, Russia
}

Received 11 August 2008; accepted 4 December 2008

\begin{abstract}
Synthetic opal crystals composed of silica spheres of diameter $\sim 250 \mathrm{~nm}$ were infiltrated with highly concentrated $(10 \mathrm{mM})$ buffered phosphate solution of iron porphyrin (FeTPPS). Magnetic circular dichroism (MCD) in the visible spectral range was investigated on hybrid samples immersed in polar (ethanol) or non-polar (hexane, toluene) solutions and situated in magnetic field. The MCD effect was observed in the spectral region of 550-650 nm in the vicinity of Q-absorption bands of FeTPPS. In $350 \mathrm{mT}$ magnetic field the relative optical transmission change by $2.4 \cdot 10^{-4}$ was determined at the $\mathrm{Q}_{0}$-band of $0.3 \mathrm{~mm}$ thick infiltrated opal sample. The dispersion-like lineshape of MCD spectra corresponded to the A-type term. An average refraction index and refraction index contrast of composite system was controlled by immersion of infiltrated opal samples into various liquids. As a result, the spectral position of the stop band in opal photonic crystal was tuned with respect to FeTPPS absorption bands. When the Q band of FeTPPS was within the stop band of opal, the optical contrast of photonic crystal was changed by external magnetic field due to the MCD effect.
\end{abstract}

Keywords: photonic band gap materials, infiltrated opal, magnetooptical effects

PACS: 42.70.Qs, 78.20.Ls

\section{Introduction}

Recently, a large research effort was devoted to the development of photonic crystals (PCs) [1] because of their promising applications in optoelectronics. In order to control photonic properties, PCs were infiltrated with different materials. A variety of tunable PCs were prepared using templates with the structure of opals and inverse opals, the voids of which were filled with metals, semiconductors, and organic compounds $[2,3]$. It was found that photonic band structure of synthetic opal could be controlled by external illumination due to infiltrated photochromic dye aggregates [4]. The stop band was continuously tuned by infiltrating mixed liquids into the voids in opal structure leading to the change of refraction index contrast of silica spheres and liquids $[5,6]$.

When one of constituent materials of a PC is magnetic, the system is treated as magnetophotonic crystal

\footnotetext{
* Results presented at the international conference Radiation Interaction with Material and Its Use in Technologies 2008, 24-27 September 2008, Kaunas, Lithuania
}

(MPC) [7] exhibiting unique magneto-optical response. Multilayered structures representing one-dimensional (1D) MPCs and consisting of alternating oxide and metal/garnet layers were fabricated [8]. An enhancement of both Kerr effect and Faraday rotation due to a strong photon confinement in the vicinity of magnetic defects was determined [7]. 1D and 2D arrays of magnetic particles of iron oxides fabricated by LangmuirBlodgett technique and layer-by-layer deposition were also considered [9] as attractive candidates for MPCs.

A series of 3D MPCs were prepared by using opal or inverse opal structures as templates. Nanocomposites of BiNi were infiltrated [10] into opal and inverse opal by heating the structure to a temperature above the melting point of the filler and applying it to a pressure of 1-2 kbar. Macroporous transition metal networks fabricated by electrochemical deposition have shown a high coercivity that could be controlled by the size of voids in the inverse opal structure prepared from polystyrene latex template [11]. Opal-magnetite and opal-garnet composites exhibited magnetic properties of the sub- 
stances embedded in the opal lattice [12]. 3D MPC was also fabricated by impregnating self-assembled opal template with $\mathrm{Tb}-\mathrm{Ga}$-garnet [13] illustrating a promising way for development of composite with a complete photonic bandgap, which could be controlled by external magnetic field. Thus, the current problem is the fabrication and testing of photonic crystals with magnetic materials for novel magnetophotonic device prototyping.

In this work magneto-optics of opal photonic crystals infiltrated with iron porphyrin (FeTPPS) was studied. Synthetic opal crystals composed of a close-packed face centred cubic (fcc) lattice of silica spheres were infiltrated with concentrated buffered phosphate solution of FeTPPS. Magnetic circular dichroism (MCD) was investigated on hybrid samples immersed in polar (ethanol) or non-polar (hexane, toluene) solutions. It was shown that the spectral position of the stop band of opal crystal could be tuned with respect to MCD feature due to absorption band of FeTPPS by varying the refractive index of immersed liquids.

\section{Experimental set-up}

Synthetic opal bulk samples were obtained on horizontal substrates by gravitational sedimentation technique from aqueous colloidal suspension of monodispersed $\mathrm{SiO}_{2}$ microspheres of diameter $D \sim 250 \mathrm{~nm}$. Self-organized close-packed 3D crystalline opal structures were obtained. Bulk structures were annealed in vacuum for $8 \mathrm{~h}$ at $900^{\circ} \mathrm{C}$ to enhance the mechanical stability. The samples of $200-300 \mu \mathrm{m}$ thickness were cut parallel to (111) plane of opal fcc lattice. Two series of opal samples with slightly smaller (series L05) and larger (series L02) diameter of silica spheres were investigated.

Aqueous solutions of FeTPPS with $1 \cdot 10^{-2} \mathrm{M}$ concentration were prepared by solving Fe(III)meso-tetra (4-sulfonatophenyl) porphine chloride (acid form) (Frontier Sci.) in standard phosphate $\left(\mathrm{Na}_{2} \mathrm{HPO}_{4}\right.$ and $\mathrm{KH}_{2} \mathrm{PO}_{4}$ ) buffered solution. Because of a high concentration, the acidic aqueous solution of FeTPPS with pH 4.2 was obtained. For infiltration, the opal samples were immersed into FeTPPS aqueous solution for several hours. After infiltration procedure the obtained composite samples were dried at $60-95^{\circ} \mathrm{C}$ for $0.5-$ $3.0 \mathrm{~h}$. The atomic force microscopy (AFM) images were typical for porphyrin-infiltrated opal crystals [14].

In optical studies the FeTPPS-impregnated opal samples were immersed in polar (ethanol) or non-polar (hexane, toluene) solutions to vary the average refrac- tive index of composite system and to control the mutual positions of the opal stop band and absorption bands of FeTPPS [6]. During multiple experimental runs, that included immersion and drying of composite samples, the optical spectra did not change significantly indicating that FeTPPS formations deposited on $\mathrm{SiO}_{2}$ spheres were stable. The cuvettes of thickness 1-2 mm with flat parallel walls were used for optical studies on samples immersed in liquids.

The MCD spectra were measured in the 450-700 nm range by means of photometric ellipsometer equipped with photoelastic modulator of light polarization operating at the frequency of $30 \mathrm{kHz}$. The circular dichroism (CD) signal $\Delta K_{\mathrm{CD}}=K_{\mathrm{L}}-K_{\mathrm{R}}$ measured in zeroorder transmission geometry corresponded to the difference in optical absorption coefficient for light modulated from left- $(\mathrm{L})$ to right- $(\mathrm{R})$ circular polarization. The magneto-optical experiments were carried out in Faraday geometry on samples located in constant magnetic field up to $350 \mathrm{mT}$. The MCD effect $\Delta K_{\mathrm{MCD}}=$ $\Delta K_{\mathrm{CD}}(B \neq 0)-\Delta K_{\mathrm{CD}}(B=0)$ was calculated as the difference of CD signal in a constant magnetic field with respect to that at zero magnetic field. The MCD spectra were symmetric for two directions of magnetic field $B^{+}$and $B^{-}$, i.e., $\Delta K_{\mathrm{MCD}}\left(B^{+}\right)=-\Delta K_{\mathrm{MCD}}\left(B^{-}\right)$.

\section{Results and discussion}

The fine structure of the optical spectra of highconcentration FeTPPS buffered solutions have been described elsewhere [6]. The MCD spectra of highconcentration (10 mM) FeTPPS solutions (Fig. 1) were similar to those observed for lower concentrations $(<1 \mathrm{mM})$ [15]. In both cases of basic solutions the optical features were ascribed to $\mu$-oxo-bridged dimer species O-(FeTPPS $)_{2}$. However, in the case of higher concentration the absorption peaks were shifted towards longer wavelengths by $10-15 \mathrm{~nm}$ for Q-bands due to interaction between dimers. The dispersion-like lineshape of A-type term [16] in MCD spectra $\Delta K_{\mathrm{MCD}}$ was well described by the model of Lorentzian-like lines. In this approximation an increase of MCD signal was due to redistribution of electronic transitions enhancing their polarization dependence in magnetic field. A similar model was applied to MCD spectra for FeTPPSinfiltrated opal samples immersed in ethanol (Fig. 1). However, as follows from detailed analysis [6], the absorption Q-bands of FeTPPS were strongly influenced by ethanol due to the formation of chemical bonds between sulfonic groups of porphyrin with silanol groups on surface of silica spheres and with ethoxy groups in 


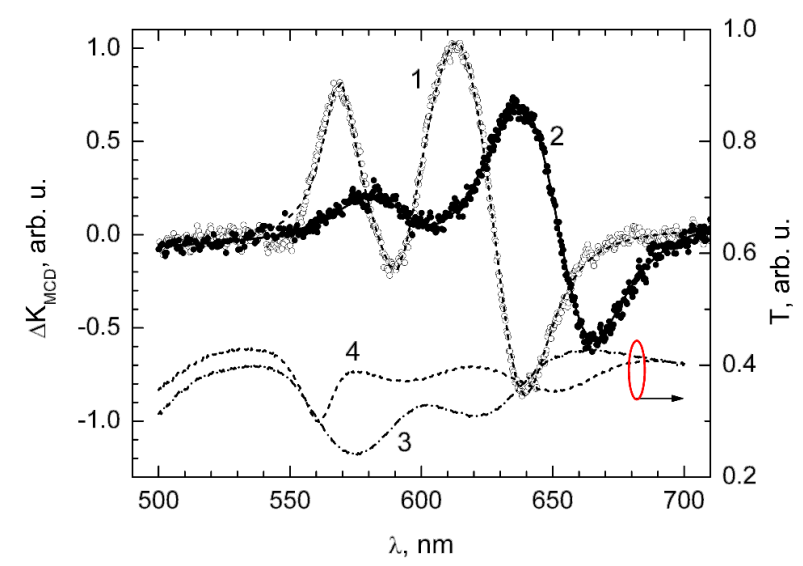

Fig. 1. Experimental (points) and calculated (curves) spectra of MCD $\Delta K_{\mathrm{MCD}}$ in magnetic field of $350 \mathrm{mT}(1,2)$ and spectra of optical transmission $T(3,4)$ for FeTPPS buffered solution $(10 \mathrm{mM}$, $\mathrm{pH} 4.2)(1,3)$ and FeTPPS-infiltrated opal sample L02 immersed in ethanol $(2,4)$.

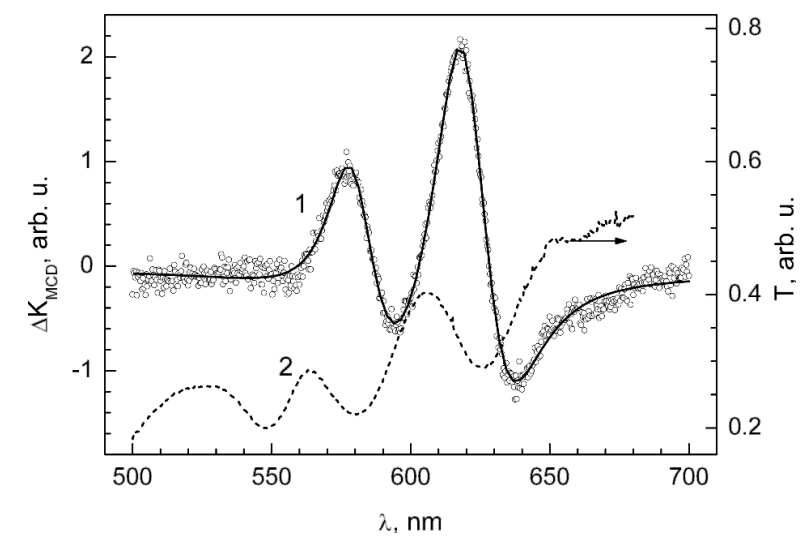

Fig. 2. Experimental (points) and calculated (curve) MCD for $B=$ $350 \mathrm{mT} \mathrm{(1)} \mathrm{and} \mathrm{experimental} \mathrm{zero-order} \mathrm{transmission} \mathrm{(2)} \mathrm{spectra} \mathrm{of}$ FeTPPS-infiltrated opal sample L05 immersed in hexane.

ethanol environment. As a result, the $\mathrm{Q}_{1}(575 \mathrm{~nm})$ and $\mathrm{Q}_{0}(620 \mathrm{~nm})$ bands were shifted towards longer wavelengths by $\sim 20$ and $\sim 30 \mathrm{~nm}$, respectively, in the opal samples immersed in ethanol. In addition, it was reasonable to propose that the $\mathrm{Q}_{1}$ component of $\mathrm{MCD}$ was influenced also by the opal stop band at $\sim 560 \mathrm{~nm}$, though these two features were separated by $\sim 35 \mathrm{~nm}$.

The MCD spectrum of opal sample immersed in hexane is presented in Fig. 2. It should be noted that Q-absorption bands of FeTPPS in the samples immersed in hexane were slightly shifted towards long wavelengths as compared with the spectrum of FeTPPS buffered solution. However, the latter shift $(\sim 5 \mathrm{~nm})$ was smaller than that for ethanol environment. The difference in position of Q-bands clearly indicated a stronger influence of polar solutions on the energy levels of FeTPPS formations deposited on silica spheres. The MCD spectra in FeTPPS-infiltrated opal crystals in hexane (Fig. 2) were also well approximated by the same model as in the case of ethanol environment (Fig. 1). The relative change of optical transmission $\Delta T / T$ for $\mathrm{Q}_{0}$ band was $\sim 2.4 \cdot 10^{-4}$ in $350 \mathrm{mT}$ magnetic field.

The MCD effect was also observed in the case when, varying the average refraction index, the stop band of opal was tuned to coincide with the Q-bands of FeTPPS (Fig. 3). The overlap of two bands of different origin, i. e., the stop band of PC and absorption band of FeTPPS, was achieved by immersion of infiltrated opal into the mixture of hexane and toluene. As seen from Fig. 3(a), the fine structure of MCD spectra was qualitatively the same, though the signal/noise ratio was worse because of the decreased optical transmission in the region of the stop band of PC. In the long wavelength region $(670-700 \mathrm{~nm})$ a small feature was resolved which could be assigned to excitation of FeTPPS monomer at $680 \mathrm{~nm}$ [15].

It is interesting to note that in the region of opal stop band, a strong CD signal has been observed. The signal was stronger in the case of a deeper stop band due to increased refraction index contrast in photonic crystal. In Fig. 3(b), the CD spectra are presented for two directions of magnetic field. The optical feature due to FeTPPS $\mathrm{Q}_{0}$ band (with maximum at $\sim 620 \mathrm{~nm}$ ) was clearly resolved in both CD and optical transmission spectra. In the vicinity of the peak, the CD signal was dependent on the direction of magnetic field. The difference in CD caused the observed MCD signal (Fig. 3(a)). In addition, the CD signal had significantly increased in the region of the stop band and was not dependent on the magnetic field (Fig. 3(b)). The CD signal increased in series of experimental runs in which the refractive index contrast was increased by immersion of opal sample in hexane-toluene solutions. The CD signal can be related to the linear birefringence of opal crystals [3] the dispersion of which increases significantly approaching the stop band. Due to the birefringence, the circular polarization of incident light transforms into elliptical at the propagation of electromagnetic waves through PC and it is registered as CD signal.

The provided experiments have shown that photonic properties could be controlled in FeTPPS-infiltrated opal crystals. The position of opal stop band with respect to absorption bands of FeTPPS was efficiently tuned by varying average refractive index of composite system immersed into liquid. It was demonstrated that the optical contrast in the vicinity of the stop band of 


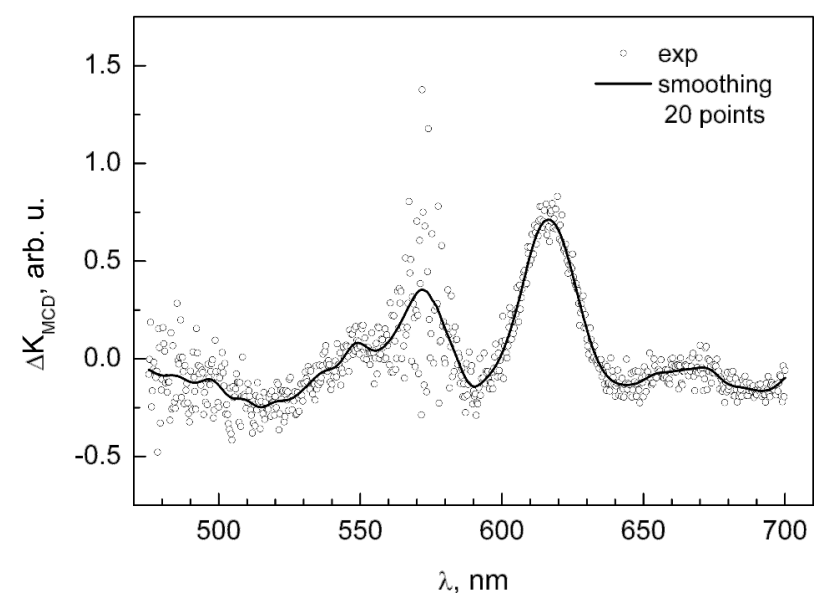

(a)

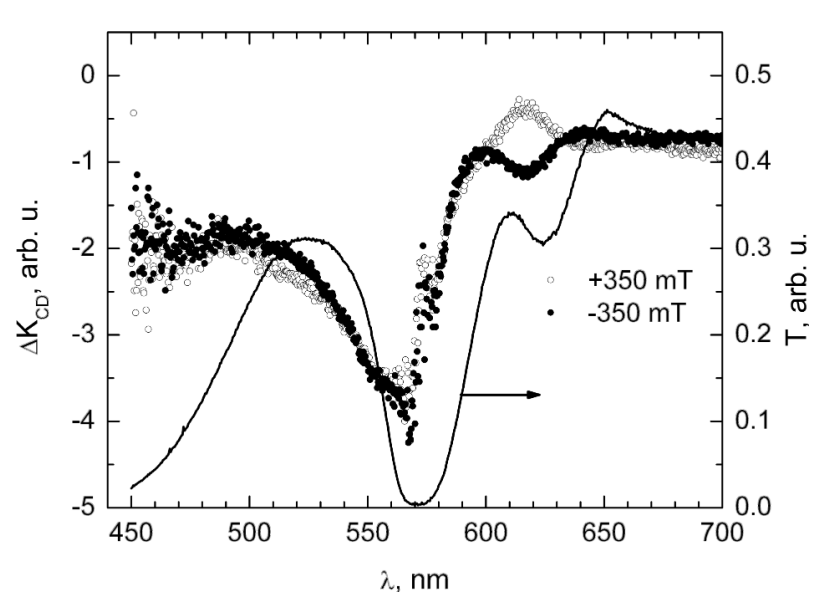

(b)

Fig. 3. (a) Experimental (points) and averaged over 20 points (curve) MCD spectrum ( $B=350 \mathrm{mT}$ ) and (b) CD spectra for two directions of magnetic field and transmission spectrum of FeTPPS-infiltrated opal sample L02 immersed in hexane-toluene mixture.

FeTPPS-infiltrated opal could be varied by an external magnetic field.

\section{Acknowledgement}

Support from the Lithuanian State Science and Studies Foundation (project T-36/08) is gratefully acknowledged.

\section{References}

[1] S.G. Johnson and J.D. Joannopoulos, Photonic Crystals: The Road from Theory to Practice (Springer, 2003).

[2] M.I. Samoilovich, S.M. Samoilovich, A.V. Guryanov, and M.Yu. Tsvetkov, Artificial opal structures for 3D-optoelectronics, Microelectron. Eng. 69, 237-247 (2003).

[3] J. Sabataityte, I. Simkiene, G.-J. Babonas, A. Reza, M. Baran, R. Szymczak, R. Vaisnoras, L. Rasteniene, V. Golubev, and D. Kurdyukov, Physical studies of porphyrin-infiltrated opal crystals, Mater. Sci. Eng. C 27, 985-989 (2007).

[4] Z.-Z. Gu, S. Hayami, Q.-B. Meng, T. Iyoda, A. Fujishima, and O. Sato, Control of photonic band structure by molecular aggregates, J. Am. Chem. Soc. 122, 10730-10731 (2000).

[5] J. Li, W. Huang, and Y. Han, Tunable photonic crystals by mixed liquids, Coll. Surf. A 279, 213-217 (2006).

[6] J. Sabataityte, I. Simkiene, A. Reza, G.-J. Babonas, R. Vaisnoras, L. Rasteniene, D. Kurdyukov, and V. Golubev, Studies of opal crystals infiltrated with iron porphyrin, Superlattices Microst. 44, 664-669 (2008).

[7] M. Inoue, R. Fujikawa, A. Baryshev, A. Khanikaev, P.B. Lim, H. Uchida, O. Aktsipetrov, A. Fedyanin,
T. Murzina, and A. Granovsky, Magnetophotonic crystals, J. Phys. D 39, R151-R161 (2006).

[8] M. Inoue, K. Arai, T. Fuji, and M. Abe, Onedimensional magnetophotonic crystals, J. Appl. Phys. 85, 5768-5770 (1999).

[9] I.L. Lyubchanski, N.N. Dadoenkova, M.I. Lyubchanski, E.A. Shapovalov, and Th. Rasing, Magnetic photonic crystals, J. Phys. D 36, R277-R287 (2003).

[10] A. Gupta, A.Yu. Ganin, P. Sharma, V. Agnihotri, L.M. Belova, K.V. Rao, M.E. Kozlov, A.A. Zakhidov, and R.H. Baughman, Synthetic magnetic opals, Pramana 58, 1051-1059 (2002).

[11] P.N. Bartlett, M.A. Ghanem, I.S. El Hallag, P. de Groot, and A. Zhukov, Electrochemical deposition of macroporous magnetic networks using colloidal templates, J. Mater. Chem. 13, 2596-2602 (2003).

[12] A.V. Baryshev, T. Kodama, K. Nishimura, H. Uchida, and M. Inoue, Three-dimensional magnetophotonic crystals based on artificial opals, J. Appl. Phys. 95, 7336-7338 (2004).

[13] H. Uchida, R. Fujikawa, T. Kodama, A.V. Baryshev, K. Nishimura, and M. Inoue, Fabrication of 3Dmagnetophotonic crystal with artificial opal template prepared by gravitational sedimentation, IEEE Trans. Magn. 41, 3526-3528 (2005).

[14] J. Sabataityte, I. Simkiene, G.-J. Babonas, A. Reza, A. Suchodolskis, M. Baran, R. Szymczak, R. Vaisnoras, L. Rasteniene, V. Golubev, and D. Kurdyukov, Modification of photonic properties in porphyrininfiltrated opal crystals, Photonics Nanost. Fund. Appl. 5, 125-128 (2007).

[15] R. Tamaševičius, I. Šimkienè, A. Rèza, I. Blažys, and G.J. Babonas, Magnetic circular dichroism of iron porphyrin, Proc. SPIE 6596, 65961E1-6 (2007).

[16] P.J. Stephens, W. Suetaak, and P.N. Schatz, Magnetooptical rotatory dispersion of porphyrins and phtalocyanines, J. Chem. Phys. 44, 4592-4602 (1966). 


\title{
GELEŽIES PORFIRINU INFILTRUOTŲ OPALO KRISTALŲ MAGNETINIS APSKRITIMINIS DICHROIZMAS
}

\author{
A. Rėza ${ }^{a, b}$, I. Šimkienè $^{a}$, G.J. Babonas ${ }^{a}$, R. Vaišnoras ${ }^{b}$, D. Kurdyukov ${ }^{c}$, V. Golubev ${ }^{c}$ \\ ${ }^{\text {a }}$ Puslaidininkiu fizikos institutas, Vilnius, Lietuva \\ ${ }^{\mathrm{b}}$ Vilniaus pedagoginis universitetas, Vilnius, Lietuva \\ ${ }^{\mathrm{c}}$ Jofés fizikos ir technikos institutas, Rusijos mokslu akademija, Sankt Peterburgas, Rusija
}

\section{Santrauka}

Tirti sintetiniai opalo kristalai, sudaryti iš $\sim 250 \mathrm{~nm}$ diametro silicio oksido sferų ir infiltruoti didelès koncentracijos $(10 \mathrm{mM})$ geležies porfirino (FeTPPS) buferiniu fosfatiniu tirpalu. Magnetinis apskritiminis dichroizmas (magnetic circular dichroism, MCD) buvo matuojamas regimajame spektro ruože, įmerkus hibridinius bandinius magnetiniame lauke i polini (etanolio) ar nepolinị (heksano, tolueno) tirpalus. MCD efektas stebètas 550-650 nm spektro ruože FeTPPS Q sugerties juostų srityje. Infiltruotu $0,3 \mathrm{~mm}$ storio opalo bandinių $\mathrm{Q}_{0}$ juostoje santykinis optinio pralaidumo po- kytis $350 \mathrm{mT}$ magnetiniame lauke buvo $2,4 \cdot 10^{-4}$. Dispersijos tipo MCD spektro linijos forma atitiko magnetooptini A tipo narị. Kompozicinès sistemos vidutinis lūžio rodiklis ir lūžio rodiklio kontrastas buvo valdomi, imerkiant infiltruoto opalo bandinius i ivairius skysčius. Dèl šios priežasties fotoninio kristalo stop juostos spektrinè padètis buvo keičiama FeTPPS sugerties juostų atžvilgiu. Kai FeTPPS Q juosta sutapdavo su opalo stop juosta, fotoninio kristalo optinis kontrastas dèl MCD efekto buvo keičiamas išoriniu magnetiniu lauku. 